\title{
Employee Performance Measurement and Performance Appraisal Policy in an Organisation
}

\author{
Michael A. Akinbowale \\ Melanie E. Lourens \\ Dinesh C. Jinabhai \\ Department of Human Resources Management, Faculty of Management Sciences \\ Durban University of Technology, KwaZulu-Natal, Durban, South Africa \\ Email: abiodunnus2002@yahoo.com
}

\section{Doi:10.5901/mjss.2014.v5n9p342}

\begin{abstract}
Performance appraisal policy has been viewed by organizations and human resources practitioners as an effective tool for human resources management. However, effective performance appraisal policy remains a practical challenge to managers and employees because of cognitive, motivational and behavioural factors. There are various methods of performance appraisal. In fact, each organization may have its own unique policy and method of appraisal. In one organization, it may be continuing and informal where personal opinion of a superior about his/her subordinates may be the basis of appraisal. In another, it may be well-defined and a particular policy and approach may be followed by all managers. Usually the method of performance appraisal dictates the time and effort spent by both supervisors and employees and determines which areas of performance are emphasized. Ideally, a performance appraisal policy should be objective, accurate and easy to perform.
\end{abstract}

Keywords: Employee, Performance, Measurement, Appraisal, Policy, Concepts, Perception.

\section{Introduction}

Performance appraisal is the strength of performance management, which in turn affects the organizational performance. It helps to identify and overcome the problems faced by the employees on his/her work (Mackey and Johnson, 2000:3). Although it has many benefits for the organization, Anderson (2002:80) states that performance appraisal have the equal probability of having a bad impact on the organization as well as on employee performance.

According to Fletcher and Bailey (2003:397), managers are perfectly capable of forming judgements of employee performance that are accurate. Fandray (2001:35) highlights "that rating inaccuracy was often a reflection of a deliberate conscious process of distortion used to serve the rater's agenda and not unconscious bias or error". According to Atkins and Wood (2002:879), employee performance ratings are bunched around either moderate or high performance. Negative information is less likely to be conveyed than positive information. Moreover, a consequence of this is the tendency to rate employees as average or above, due to the interpersonal awkwardness of telling employee their performance is below average (Rechter, 2010:63). Byron (2007:728) states that "there is a tendency to mark at the middle of the scale or higher and raters may avoid giving negative news, because they employ empathic buffering". According to Hunt (2005:268), there is evidence to suggest that in performance appraisal policy, managers are using ratings to achieve goals that are contrary to the goal of providing accurate employee performance ratings. Ratings may be motivated by a fear of conflict with poor performing employee. Moreover, inflation may also be used to improve an employees' performance by increasing self-efficacy (Mackey and Johnson, 2000:8). Managers might also consistently inflate ratings to protect their employees' reputation as good managers, if employees are seen to be performing poorly and this may reflect badly on the manager (Rudman, 2003:6).

According to Rudman (2003:437), performance appraisal has a positive and negative impact. Employees who receive a good score on his/her appraisal are generally motivated to perform well and maintain his/her performance. Positive feedback on appraisals gives employee a feeling of worth and value, especially when accompanied by salary increases. If a supervisor gives an employee a poor score on his/her appraisal, the employee may feel a loss of motivation in the workplace. Consequently, this can impact on the employee's performance (Cook and Crossman, 2004:527). 


\section{Objectives of the Study}

- To examine the impact of performance appraisal policy for measuring employee performance.

- To investigate the relationship between performance appraisal policy and employee performance.

\section{Literature Review}

\subsection{The Purposes of Measuring Employee Performance}

According to Rechter (2010:65), the prevailing culture within the organization is often seen as being driven by power of the elite, a clique which controls the organization's norms from above. This is an example of the influence of politics within organizations. Levinson (2005:3) contends that there exists a deliberate manipulation of performance appraisal policy for political purposes, such as getting rid of subordinates and scaring or punishing poor employees. Byron (2007:728) suggests that the impact of political influences is less in the assessment of lower level employees in organizations but has a major impact at higher levels within organizations.

\subsection{The Need for Employee Performance Measurement}

According to Cook and Crossman (2004:517), the problem of rating inflation also appears to be related to the personality of the rater. In situations where poor supervisor ratings are likely to result in conflict, managers high on the personality dimension agreeableness inflate their ratings much more than those who describe as low on the dimension (Smither and Walker, 2004:253). This appears to be because those high on agreeableness rating appear to be particularly keen to avoid conflict situations. Therefore, they tend to inflate their ratings more when they know they will have to continue working with the employee in the future and they are aware that the employee sees his/her as a good performer (Anderson, 2002:2). It also suggests that there should be some component in appraiser training that helps raters to develop skills that will help to deal with conflict. Dessler and Gary (2000:322) contend that the issue of rater self-efficacy in terms of whether the employee believes that they can deal with potential conflict effectively. On this basis, developing the rater's belief that they can deal with potential conflict from a disgruntled poor employee performance could reduce the rater's motivation to inflate their ratings.

\subsection{The Concepts of Performance Appraisal on Employee Performance}

Rechter (2010:25) states that in many organizations performance appraisal policy is still a matter of rewarding employee as individuals. While performance appraisal may be a part of policy which encourages competition between colleagues, these colleagues may be required to perform as team members (Freeman, 2002:196). Thus, an employee may be in an unpleasant position whereby they are officially expected to depend on their performance as an individual, often in competition with his/her team mates. This emphasis creates a problem for the performance of the employee (Mello, 2010:439). According to Mondy and Noe (2008:5), organizations may not state that employees have to stay at work beyond the usual office hours. However, when an employee sees his/her colleagues staying late they may be reluctant to leave the office due to a feeling that they may not be pulling their weight in some way. The employees join their office culture of staying at work late, while any possible benefits to employee performance may be questionable (Wade and Ricardo, 2001:3). Kuvaas (2006:509) states that with regards to performance appraisal policy, there may be an issue as to how much control the employee feels they have in his/her work environment. Coens and Jenkins (2000:232) carried out a meta-analysis on research studies that looked at participation in the performance appraisal policy and now differentiated between:

- Instrumental participation that allows the employee to influence the outcomes of the performance appraisal policy; and

- Value expression that allows the employee to voice his/her opinions irrespective of the influence this may have.

Freeman (2002:196) indicated a strong relationship between participation and employee satisfaction, with value expression being the more important of the two. Atkins and Wood (2002:879) highlight that multi-rater techniques often allow the employee to rate themselves so that his/her own views can be considered in the performance appraisal policy. Furthermore, it helps employees feel more involved and satisfied with the policy and other raters can be influenced by the 
employees' self-rating. Fineman (2006:271) contends that when raters were aware that an employee had overestimated his/her performance, the raters tended to inflate his/her ratings of that employee in order to avoid conflict. Coens and Jenkins (2000:232) state that in organizational settings, it is often the case that the employees do not always show what they can do because they do not want to be manipulated. Moreover, performance appraisal policy is supposed to be about the employee's performance. This should have benefits for the organizations as the employee may often feel that the organization uses the performance appraisal policy to reinforce organizational norms. This may be done by rewarding behaviours which fit in with organizational norms while being negative about behaviours which do not fit in with organizational norms (Anderson, 2002:517). Fineman (2006:271) states that this may sometime set aside issues of how appropriate any of these behaviours are in a professional sense.

\subsection{How to Measure Employee Performance}

The most difficult part of the performance appraisal policy is to accurately and objectively measure the employee performance (Bond and Fox, 2007:5). Measuring the performance covers the evaluation of the main tasks completed and the accomplishments of the employee in a given time period in comparison with the goals set at the beginning of the period (Rudman, 2003:4). According to Kuvaas (2006:508), measuring also encompasses the quality of the accomplishments, the compliance with the desired standards, the costs involved and the time taken in achieving the results. Bond and Fox (2007:5) contend that measuring employee performance is the basis of performance appraisal policy and performance management. Accurate and efficient performance measurement not only forms the basis of an accurate performance review but also gives way to judging and measuring employee potential (Fletcher and Bailey, 2003:360).

For the purpose of measuring employee performance, different input forms can be used for taking the feedback from the various sources like the supervisor, peers and the employee (Mello, 2010:439). According to Rudman (2003:4), all the perspectives thus received should be combined in the appropriate manner and to get an overall, complete view of the employees' performance. According to Anderson (2002:2), for an organization to be effective for its goals, it is very important to monitor or measure its employee performance on a regular basis. Effective monitoring and measuring also includes providing timely feedback and reviews of the employees for their work and performance according to the predetermined goals and solving the problems faced (Mani, 2002:142). Rudman (2003:12) highlights that timely recognition of the accomplishment also motivates and helps to improve the performance of employees.

According to Aguinis (2009:2), measuring the performance of the employees based only on one or some factors can provide with inaccurate results and leave a bad impression on the employees as well as the organization. For example, by measuring only the activities in employee's performance, an organization might rate most of its employees as outstanding, even when the organization as a whole might have failed to meet the goals and objectives. Therefore, a balanced set of measures should be used for measuring the performance of the employees (Kuvaas, 2006:509).

\subsection{Performance Appraisal as a Policy for Managing Employee Performance}

According to Freeman (2002:9), employees often find themselves in situations where they must change direction frequently. Therefore, the employee seeks constant feedback to determine whether the direction they are working is what is expected by the organization. Rechter (2010:239) contends that the performance appraisal policy for employees must be frequent, accurate, specific and timely. Levinson (2005:427) highlights that it is becoming increasingly popular for organizations to ask employees to evaluate the performance of their colleagues and it is especially true with the increased focus on the use of teams in the workplace. Hunt (2005:3) states that while there is general agreement that peer evaluation provides a more complete picture of employee performance, the acceptance of peer performance appraisal policy by employee is generally low. Levinson (2005:427) contends that peer evaluation may be guided by social comparison processes whereas, because of the obviously different supervisor-subordinate relationship, supervisor evaluations would likely not follow a social comparison process. According to Dessler and Gary (2000:24), many organizations are scrapping the traditional performance appraisal policy in favour of performance management. Wade and Ricardo (2001:319) highlight that a new approach focuses on coaching and feedback. In such a policy the manager and the employee agree upon goals. Goals should be flexible to reflect changing conditions in the economy and workplace and employees should think of their managers as coaches who are there to help them achieve success.

According to Mondy and Noe (2008:4), in some performance appraisal policies, the employee is passive. Therefore, the employee does not have a significant input to the process. They merely receive an evaluation on their performance over the given performance appraisal policy period. However, in general the performance appraisal policy 
interview is a sensitive interpersonal situation, where the skill of the appraiser and maturity of both parties are keys to whether a successful outcome is reached. Mackey and Johnson (2000:204) state that in practice, emotional tension and defensiveness is the outcome of the interaction of the superior and subordinate in sharing performance appraisal policy information in the feedback interview. Furthermore, this can be a real block to employee development and while this is a potential danger, it does not have to be the case. Fineman (2006:270) highlights that managers' ability to perceive subordinates' emotions has an impact on the subordinate's satisfaction with the performance appraisal process.

\subsection{Perception of Performance Appraisal Policy}

According to Fineman (2006:270), performance appraisal policy is the best tool for measuring employee performance and guiding employee development and improvement. However, performance appraisal policy can be a frustrating ritual of the modern organization. Stone (2002:22) states that the most frequent complaint is that a large number of managers are poorly trained in how to give feedback to employees and they provide little coaching, mentoring or support. Moreover, performance appraisal policy procedures are often poorly designed, making the policy cumbersome and difficult to administer. Freeman (2002:2) contends that employees often place the entire burden of the review policy on the supervisor, doing little throughout the year to seek feedback on employee performance, avenues for improvement or development.

\subsection{Employee Attitudes towards Performance Appraisal Policy}

According to Stone (2002:3), employees often assume a defensive position when deficiencies are pointed out. This is especially true if pay, recognition or rewards are at stake. In addition, employees will resist a policy that is perceived to appraise or reward unfairly (Freeman, 2002:25). Hunt (2005:2) highlights that conflicts on the purposes and goals of a performance appraisal policy often exist when implemented. The performance appraisal policy must be part of a performance management policy that emphasizes ongoing communication and coaching in order to motivate the employee (Mondy and Noe, 2008:261). The significant barriers to the implementation of an employee performance appraisal policy are often neglected (Grote and Grote, 2002:232). While performance appraisal policy may improve employee performance, ill-prepared performance appraisal policy can adversely impact on employee performance (Fandray, 2001:35). Wade and Ricardo (2001:26) contend that commitment from the organization to conduct performance appraisal policy correctly is essential. This includes logistical and technical support, in-depth job analysis and on-going training.

According to Roberts (2002:334), managers may often fail to provide timely and accurate expectations and feedback to employees regarding performance. When feedback is provided, it is often communicated incorrectly thereby reducing morale and further reducing employee performance (Stone, 2002:123). Furthermore, employee groups often oppose the implementation of a performance appraisal policy. This is due to a variety of factors including distrust of management's ability, a perception that the performance appraisal policy is unfair and a traditional emphasis on superiority rules (Levinson, 2005:38).

\section{Discussion and Conclusion}

According to Armstrong (2001:475), the issues of accuracy and fairness in performance appraisal is one of the key research interest. In the field of Human Resources management, performance appraisal may be used as a means of measuring employee performance. The purpose of measuring employee performance is not to indicate only where things are not going according to plan but also to identify why things are going well so that steps can be taken to build on success (Levinson, 2005:4). The goal of performance appraisal is to access and summarize employee performance and develop future work, performance goals and expectations. Performance appraisal therefore is an important human resources function, which provides management with a systematic basis for effectively recognizing and evaluating the present and potential capabilities for human resources. The supervisors should continuously determine how effectively their subordinates are performing different tasks. Employees should be appraised at least once in a year, as this will contribute to increase employee efficiency and performance (Rudman, 2003:437).

According to Armstrong (2001:474), performance appraisal policy is a joint process that involves both the supervisor and the employees, who identify common goals, which correlate to the higher goals of the organization. If employees are effectively appraised, then the organization will experience increased performance and improved quality of output (Peiperl, 2005:62). Anderson (2002:197) states that when employees are treated with care, shown trust, 
listened to and encouraged to do better, then they reciprocate by being responsible and productive. For effective development and utilization of the human talent, performance appraisal policy plays a key role since it enables an organization to identify objectively the employee's strengths and weaknesses (Rudman, 2003:2). The organization will then be able to counsel the employees to improve on weak areas. This will help all the employees to contribute positively to the attainment of the organization objectives (Mani, 2002:142).

According to Bond and Fox (2007:97), performance appraisal policy is smooth and indirect. Most private organizations make greater investment in employee and the skill necessary to be effective with others. It is also used for linking training and development, performance planning and a tool to encourage employees to perform to their optimum potential (Mani, 2002:142). Peiperl (2005:62) highlights that the policies establish general procedures for such evaluations and delegates oversight on specific formats and detailed procedures to the line manager of an organization. Organization do utilize performance appraisal policies that suit their original strategies, therefore performance appraisal policies vary from organization to organization (Anderson, 2002:14).

Performance appraisal policy is more prevalent in the private sector, but its usage in the public sector is also increasing (Anderson, 2002:197). There is a need for an effective performance appraisal policy in an organization in order to improve employee performance as the current policy has shortcomings or may be outdated in the light of new emerging trends. Furthermore, it has the potential capacity to improve employee performance and drive organizational performance. For the employees who have a strong desire to find out how well they are doing, this is the only means they have to obtain feedback (Kuvaas, 2006:510).

\section{References}

Aguinis, H. (2009). Performance Management. 2nd Edition. Upper Saddle River, NJ: Pearson Prentice Hall.

Anderson, J.R. (2002). Measuring Human Capital: Performance Appraisal Effectiveness. Paper presented at the Human Resource Track Midwest Academy of Management Conference. Kansas City: Missouri.

Armstrong, M. (2001). A Handbook of Human Resources Management Practice. 8th Edition. London: Kogan.

Atkins, P. \& Wood, R. (2002). Self-Versus others' ratings as predictors of assessment centre ratings: Validation evidence for feedback programs. Personnel Psychology. 55(2): 871-907.

Bond, T. \& Fox, C. (2007). Applying the Rasch Model: Fundamental Measurement in Human Sciences. 2nd Edition. New Jersey: Lawrence Album Associates.

Byron, K. (2007). Male and female managers' ability to read emotions: Relationships with supervisors performance ratings and subordinates satisfaction ratings. Journal of Occupational and Organisational Psychology. 80(4): 706-732.

Coens, T. \& Jenkins, M. (2000). Abolishing performance appraisals: why they backfire and what to do instead. 1st Edition. San Francisco, CA: Berrett-Koechler Publisher.

Cook, J. \& Crossman, A. (2004). Satisfaction with performance appraisal systems. Journal of Managerial Psychology. 19(5): 526-541.

Dessler, D. \& Gary, R. (2000). Human resources Management. 8th Edition. Harlow: Prentice Hall.

Fandray, D. (2001). The new thinking of performance appraisals. Workforce. 80(5): 35-44.

Fineman, S. (2006). On being positive: Concerns and counterpoints. Academy of Management Review. 31(2): 230-310.

Fletcher, C. \& Bailey, C. (2003). Assessing Self-awareness: Some Issues and Methods. Journal of Managerial Psychology. 18(5): 395404.

Freeman, J. (2002). How to improve the effectiveness of performance management and appraisal by overcoming the root cause of the problem. The Human Resources Management Guide Network [Online]. Available: http:www.hrmguide.com/performance. Date accessed: 17 December 2011.

Grote, R.C. \& Grote, D. (2002). The performance appraisal question and answer book: A survival guide for managers. New York: Broadway.

Hunt, N. (2005). Conducting Staff Appraisals: How to set up a Review System that will ensure fair and effective appraisal and improve individual performance and organizational results. How to Books, 5th Edition. Oxford: Jordan Hill.

Kuvaas, B. (2006). Performance Appraisal Satisfaction and Employee outcomes; mediating and moderating roles of work motivation. International Journal of Human Resources Management. 17(3): 504-522.

Levinson, H. (2005). Management by Whose Objectives. Harvard Business Review on Appraising Employee Performance. Harvard Business School Publishing. Boston: Allyn \& Bacon.

Mackey, K. \& Johnson, G. (2000). The Strategic Management of Human Resources in New Zealand. Auckland: Irwin/McGraw-Hill.

Mello, J.A. (2010). Strategic Human Resources Management. 3rd Edition. Mason, Ohio: South Western.

Mondy, W. \& Noe, R. (2008). Human Resources Management. 10th Edition. Harlow: Prentice Hall.

Peiperl, M. (2005). Getting 360-degree Feedback Right. Harvard Business Review on Appraisal Employee Performance. Harvard Business Publishing. Boston: Allyn \& Bacon.

Rechter, E. (2010). Emotional and cognitive reaction to feedforward intervention. Paper presented at the 11th Annual meeting of the society for personality and social psychology. Kansas City: Missouri.

Roberts, G.E. (2002). Employee performance appraisal system participation: 
A technique that works. Public Personnel Management. 31(3): 332-372.

Rudman, R. (2003). Human Resources Management in New Zealand. Auckland: Pearson Education New Zealand Limited.

Smither, J. \& Walker, A. (2004). Are there characteristics of narrative comments related to improvement in multi-rater feedback ratings over time. International Journal of Applied Psychology. 89(3): 554-578.

Stone, R. (2002). Human Resources Management. 4th Edition. Brisbane: Wiley.

Wade, I. \& Ricardo, R. (2001). Corporate performance management. How to build a better organisation through measurement - Driven strategic Alignment. Butterworth: Heinemann. 